\title{
Revisiting island decolonization: The pursuit of self-government in Pacific island polities under US hegemony
}

\author{
Moritz Pöllath \\ Ludwig Maximilian University of Munich, Germany \\ Moritz.Poellath@Irz.uni-muenchen.de
}

\begin{abstract}
The final years of the Cold War and the following decade led to a short historical intermission in the United States' strategic interest in the Pacific. During that period the Trust Territory of the Pacific was dissolved and three former districts gained their independence as the Republic of Marshall Islands, the Federated States of Micronesia, and the Republic of Palau. The Commonwealth of the Northern Mariana Islands, American Samoa, and Guam, which became unincorporated US territories, remain constitutionally linked to the United States and their political status unresolved. From the legal perspective of the United Nations only American Samoa and Guam are still considered non-self-governing territories and thereby covered by the Special Committee on Decolonization. The return of geopolitical competition to the Pacific due to the rise of China is reviving the question of self-determination in these island polities anew. At the same time, the intention remains to preserve the political and economic links with the United States, calling into question traditional concepts of decolonization. This study will analyze Pacific islanders' current pursuit of self-government under US hegemony, in order to clarify whether or not these islands are still determined by the process of decolonization or are taking different paths.
\end{abstract}

Keywords: decolonization, island polities, Pacific, self-government, US hegemony

https://doi.org/10.24043/isj.46

(C) 2018 - Institute of Island Studies, University of Prince Edward Island, Canada.

\section{Introduction}

"Is the Pacific a colonial or postcolonial realm?” Matsuda's (2006, p. 780) question serves as a starting point to scrutinize the UN's term 'to be decolonized' for Non-Self-Governing Territories. A first cursory look at historical and current case studies of 'US-affiliated states' (Gallen, 2015, p. 176) in the Pacific reveals three categories of "varying degrees of independence" (Quanchi \& Adams, 1993, p. 150): Hawai'i became the 50 th state of the United States in 1959. American Samoa and Guam are organized as unincorporated territories, and the Northern Mariana Islands have formed a Commonwealth with Washington, all administered by the Office of Insular Affairs. The Marshall Islands, Federated States of Micronesia (FSM), and Palau have become sovereign states in free association with the United States. 'Island polities' will be used as an umbrella term to cover all of these degrees of independence.

At a first glance, these case studies confirm the differentiation between decolonization in terms of process and self-government in terms of the end-result. Yet, the political developments in the Pacific challenge established definitions of decolonization as a mere "process of imperial dissolution" (Shipway, 2000, p. 3) and the requirement that all hidden aspects of institutional and cultural forces, even after political independence, have to be dismantled (Ashcroft et al., 2007, p. 52). In all cases, a primacy of decisions made at foreign capitals can be acknowledged, but this often did not translate one-to-one on the islands and 
had to be negotiated with the Pacific islanders. The United States' political and economic influence in the Pacific island polities remains strong to this day, but at the same time political opposition against its influence has followed a different trajectory in comparison to the wars of independence against the European empires during the decolonization of Africa and Asia. This observation gives an indication of the difficulty in defining the state of decolonization for island polities in the outgoing $20^{\text {th }}$ century and at the beginning of the $21^{\text {st }}$ century.

The UN Resolution 65/119 'Third International Decade for the Eradication of Colonialism' demands that the administering powers of the remaining Non-Self-Governing Territories pursue and implement a course of decolonization as stated by the relevant UN resolutions (United Nations, 2010). In this political framework, the US-affiliated island polities offer diverse case studies which are questioning the concept of decolonization for the Pacific while acknowledging at the same time the power disparities among non-selfgoverning territories, island states, and administering powers. Baldacchino (2010, p. 190) remarks that "sovereignty does not appear to be any longer the obvious trajectory of peoples who see themselves as dispossessed political entities or at the losing end of federalist developments. In the contemporary world, there may be solid definitive advantages in not being independent." Petersen (1998, p. 199) recognizes in his studies on Micronesia that independence as an either/or matter is a far too inflexible perspective "to explain the nuances of international relations." Thus, in order to abandon "absolute and binary understandings of independence and dependence" (Grydehøj, 2016, p. 106), it is necessary to analyze the degree of sovereignty and control over foreign and domestic matters. Hence, it will be argued that the concept of decolonization remains confined to a historical period and that selfdetermination, dependency arrangements, and degrees of political independence offer more fitting terms for the political issues of island polities.

This paper's focus on formal legal mechanisms, constitutional issues, international relations, and diplomacy means that, by its very nature, it addresses discussions of 'high politics'. Such an approach cannot help but engage in the discursive framework of metropolitan states and powerful political actors rather than those of people who, for whatever reasons, lack political power at present. This paper's arguments should thus not be interpreted as attempting to represent the rights or voices of Pacific islanders themselves. Its scope is instead limited to legal, constitutional, and diplomatic perspectives from the field of high politics.

\section{Pacific island polities in an era of US expansion and contraction}

The relationship between the United States and the Pacific can be expressed from a geopolitical perspective as "expansion and contraction" (Crocombe, 1995, p. 269). US expansion in the Pacific occurred on a step-by-step basis without a grand design to acquire territory. A network of US naval bases was sought by Washington in accordance with Alfred Thayer Mahan's strategy to protect commercial interests and project power if necessary (Mahan, 1935, pp. 27-29). In 1898 the Spanish-American War led to the acquisition of Guam and the result of the Samoan Crisis (1887-1889) extended American sovereignty over Eastern Samoa-later American Samoa (Stayman, 2009, p. 5).

The Second World War fundamentally changed the American presence in the Pacific: after the high number of fatalities among US soldiers in the war against Imperial Japan, the emergence of a vast American Pacific Empire became a possibility. Yet, Franklin D. Roosevelt wanted to avoid following in the footsteps of the European colonial powers and insisted on a regime of trusteeship. Despite Roosevelt's intentions, the historical events led to the undisputed fact that Washington had established a sphere of influence in the Pacific characterized by the four "American flag islands": Hawai'i, Guam, the Commonwealth of the Northern Mariana Islands (CNMI), and American Samoa (Crocombe, 1995, p. 274). The ensuing Cold War underlined once again the military and strategic value of the Pacific islands 
for the containment of the Soviet Union. Independence or self-determination were postponed, and a UN Trust Territory of the Pacific Islands (TTPI) was created by the Security Council on 2 April 1947 (Rothermund, 2006, pp. 50-51).

Cocrombe's alternation of the US presence in the Pacific between expansion and contraction is refined by Stayman (2009), who distinguishes between three phases of US territorial policy: Phase one was characterized by the Northwest Ordinance of 1787, which gave Congress the power and flexibility to manage the expansion from 13 to 50 states in the course of 175 years. This flexibility also allowed for the inclusion of non-contiguous territories like Alaska and Hawai'i into the political union. In phase two, at the turn of the $20^{\text {th }}$ century, the acquisition of remote islands in the Pacific on a primarily strategic premise gave rise to the accusation of colonialism, which stood in conflict with America's own historical selfperception, but at the same time not in the way of a growing imperialistic presence abroad. In order to legally clarify the US presence in the Pacific, the Supreme Court decided through the 'Insular Cases' that the United States could acquire territory without the extension of all the benefits of the US Constitution. In due course, the political status of 'unincorporated territory' was created (Stayman, 2009, pp. 5-7). The status of 'unincorporated territory' meant that fundamental individual rights were protected by the Constitution, but "Congress need not extend citizenship nor extend a promise of eventual statehood" (Stayman, 2009, p. 7).

After the Second World War, the territorial expansion halted, and Washington worked with the United Nations to address the political future and development of these Pacific islands. In this third phase, assistance and disinterest correlated with the alternating perception of danger during the Cold War (Stayman, 2009, p. 8). After the Portuguese Carnation Revolution of 1974 ended one of the oldest European colonial empires, scholars like Rothermund (2006) saw the era of decolonization fading away. For the Pacific region, Rothermund's observation of post-1970s relations between administering powers and NSGT are relevant and correspond with Stayman's third phase of the United States' presence in the Pacific: "In some cases this was not due to the die-hard perseverance of the colonial rulers but to the material interests of the colonized. Where they had free access to the metropolitan country and also derived other economic benefits from their continued status as a colony or 'overseas territory', they preferred this attachment to independence" (Rothermund, 2006, p. 44).

This observation leads to the present state of relations between the US and the Pacific islands. The rise of China in the Pacific has put an end to the phase of contraction. President Barack Obama initiated a 'pivot to Asia' which has once again returned the strategic imperative to Oceania. In 2011, together with Prime Minister Julia Gillard, Obama announced the stationing of US Marines and Air Force units in Darwin and the Northern Territory, Australia (White House, 2011). In this era of competition and cooperation between China and the US, the unincorporated territories of American Samoa and Guam, as well as the CNMI and the states in free association with the United States, have to negotiate their political aspirations and economic development. Aside from geopolitical upswings and downturns, interactions between and among American traders, missionaries, explorers, and Pacific islanders have been steadily increasing since the mid-19 $9^{\text {th }}$ century, and today many Pacific islanders live in the United States: whether as migrants, American nationals, or citizens. These social, economic, and historical links are influencing current reflections in the USaffiliated island polities and territories. In particular, the unincorporated island polities exist in a "status limbo" and are lacking a policy-guiding principle. It remains to be seen whether statehood, independence, or free association is their ultimate goal (Stayman, 2009, p. 23).

\section{Revisiting decolonization: theoretical groundwork}

The conventional definition of decolonization of earlier scholars saw the fulfillment of decolonization with the withdrawal "of the colonial powers from direct legal and 
constitutional control over their territories" (Firth, 2000, p. 314). This definition would allow for only two analytical categories: constitutional arrangements that permitted sovereignty and forms of non-sovereignty. Non-sovereignty in turn can occur in the form of "incorporation by a metropolitan state and semi-autonomy" (Firth, 1989, p. 75). Based on the premise of Alan James's (1986, pp. 24-25) definition of sovereignty-meaning constitutional independence-the freely associated states (Marshall Islands, Federated States of Micronesia, and Palau) cannot be considered sovereign. James's constitutional approach sets aside the possibilities of varying degrees of sovereignty (Firth, 1989, pp. 75-76). While this strict categorization can help to organize international relations into sovereign and non-sovereign entities, it poses an analytical problem: it precludes the possibility of simultaneous chosen political dependence and decolonization. As long as Pacific island states are constitutionally tied to the United States, even loosely through free association, they would have to be considered unfree and thereby not fully decolonized. This approach remains a helpful path for analyzing the constitutional situation in the Pacific, but emanating from Firth's (2000, p. 315) valuable groundwork that "the simple constitutional model of Pacific Islands decolonization [...] no longer encompasses the complex reality of the issue," the question lingers: Is the notion of decolonization still relevant for these Pacific islands?

Colonialism is generally characterized, according to Philip Curtin, an Africa historian, by domination of cultural foreigners over indigenous people (as cited in Osterhammel, 2002, p. 19). Osterhammel (2002, pp. 19-21) further refines this definition: colonial rule has to encompass an entire society and rob it of its own historical self-development. Also, foreign rulers show no interest in acculturation but pursue forms of cultural dominance over the colonized. Lastly, colonialism is marked by an ideology to civilize the colonized people, viewing indigenous people as 'savages' or 'barbarians'.

While these are valid aspects of colonial rule, which can further be differentiated into settler colonies, exploitation colonies, plantation colonies, internal colonies, and colonial bases around the world, Jansen and Osterhammel (2013) offer three perspectives on decolonization: 1) a conservative imperial perspective focuses on the decline of empires, and works by Rudolf von Albertini or R. F. Holland have been criticized for a narrow view on events that initiated the end of empire; 2) a local perspective assumes the perspective of colonial or regional actors in their fight for liberation; and 3) an international perspective uses political and diplomatic sources and is characterized by Rothermund as a discrete school of decolonization but actually finds itself in line with the distinguished field of international history (Mar, 2016, pp. 6-9). A fitting critique of the term 'decolonization' comes from Gungwu (2003) and is based on an international perspective of historical events. While it is true that decolonization did not end with the mere transfer of power from the colonizers to the colonized (Frey, 2002, p. 400), the 1970s marked a starting point to call its further use into question. Some studies speak of "continuing decolonization," which leads to the question of whether there are any temporal boundaries. Thus, scholarly works should not ignore Gungwu's (2003, p. 271) criticism that "almost everything could be made to appear to have something to do with the fact that decolonization had not been fully achieved."

Gungwu's observation is supported by the Pacific region's experience of overlapping historical processes from the end of colonial rule to the present: Pacific islanders were integrated into the global anti-communist containment, pursued cooperation through the Pacific Islands Forum, experienced integration in the global economy, and migrated to the metropolitan powers. To ascribe all these historical processes to decolonization would lead to an overworked term that would stretch the meaning of decolonization too far in all directions (Gungwu, 2003, p. 270).

In the following case studies, the questions of decolonization and sovereignty will be analyzed from an international perspective, to take into account the "major structural shift in the international system" (Shipway, 2008, p. 2) since the end of the Cold War. A narrow 
constitutional view would lead to the quick and short answer that unincorporated islands and island polities are not fully sovereign. Shipway's (2008) argument to reconcile the bigger international perspective with individual national narratives of former colonies to gain a more complete understanding shall guide the analysis. Baldacchino and Milne (2010) have tackled the difficulty of island jurisdictions, which often defy clear definition. Islands pragmatically respond "to the challenges of a changing global system in concert with their partners. The patterns vary enormously, as do the constitutional choices and options" (Baldacchino \& Milne 2010 , p. 500). Sovereignty has been diminished by the forces of globalization, decentralization, and supranational integration. As a consequence, some subnational island jurisdictions (SNIJs) have slowed down their pursuit of complete independence.

In the Westphalian sense of state sovereignty, subnational island jurisdictions display "innovative autonomy arrangements that fall short of full sovereignty" (Baldacchino \& Hepburn, 2012, p. 556). These "rich breeding grounds for unique adaptations of governance in the modern world" (Baldacchino \& Milne, 2006, p. 491) are not easy to categorize, and boundaries between autonomy and sovereignty are fluid. US-affiliated islands in the Pacific are marked by "'hybrid' forms of government" (Levine \& Roberts, 2005, p. 279) which reflect the contested issue of sovereignty of these small islands. A hybrid form of sovereignty exists between two intertwined entities with constitutional links or shared jurisdictions while an entity can be said to exist in partial sovereignty when only one or more policy fields are under the control of an outside power. Adapted from research by Baldacchino, Grydehøj, Hepburn, Milne, Levine, and Roberts, this paper attempts to categorize the case studies into hybrid or partial sovereignty in order to question whether the island polities in the Pacific under US hegemony can still be considered to be in a state of decolonization in the $21^{\text {st }}$ century.

The categorization will be guided by three analytical dimensions. Firstly, the hard fact of constitutional sovereignty as Firth (1989, pp. 77-78) put forward will remain a key factor. Secondly, the continuing extent of Washington's informal empire over Pacific islands and island polities can shed light on the remaining decolonization agenda of the UN. And, thirdly, bilateral and regional diplomatic efforts by Pacific island polities can elucidate the degree of political independence. The third aspect is also the latest instrument to analyze the current political situation. The establishment of the South Pacific Forum (renamed the Pacific Islands Forum in 2000) has brought forward a multitude of activities that shape the Pacific region: new institutions of cooperation were created, and regional identity was underlined, giving Pacific islanders a stronger voice in international affairs. Fry and Tarte (2015, pp. 3-4) rightfully assess a profound "transformation of the regional diplomatic culture equivalent to the move from the colonial to the postcolonial era." Put together, all three aspects can deliver a revised position on the decolonization of Pacific islands under US hegemony.

\section{The Commonwealth of the Northern Mariana Islands}

Micronesia is aptly described by David Hanlon (1998, p. 1) as "the most peripheral of peripheries." As one of the former districts of the Trust Territory of the Pacific Islands, the CNMI provides a good starting point to "lift a bit the blanket of American domination to see what lies under it" (Hanlon, 1998, p. 4). The UN Trust Territory, which comprised the islands of Micronesia north of the equator, endured from 1947 to 1994. Until the 1960s, it was marked by US disinterest in the development of the Pacific islands, when Washington began pouring "several hundred million dollars in development assistance" (Stayman, 2009, p. 8) into the islands. The Cold War served as a catalyst for monetary engagement and development in the 1960s and 1970s. The massive investment in these tiny islands by the United States, in addition to the offer of US citizenship, influenced the people of the District of the Northern Mariana Islands in 1976 to separate from the TTPI. After two referenda in 
1975 and 1977, a Commonwealth of the Northern Mariana Islands (CNMI) in political union with the United States was established.

The political union with the United States brought the CNMI less political independence than the FSM or the Marshall Islands would gain through their negotiations with Washington. Yet, the Commonwealth gained its own local government with some control over immigration. The incorporated status provided the indigenous people with US citizenship and full rights to enter and work in the USA since 1986. It is important to note that the commonwealth construct also gave the people of the Northern Mariana Islands more local governmental influence than they would have had as a federal state such as Hawai'i (Crocombe, 1995, p. 32).

In the covenant between the CNMI and the US, the Northern Mariana Islanders secured an exemption from certain US federal laws that would have changed their cultural concepts of land ownership: as in American Samoa, "non-indigenous persons cannot own land, but may only lease real property from indigenous owners" (Stayman, 2009, p. 20). In 2008, the legislative authority of the CNMI was diminished when federal legislation amended the covenant: until 2008, control over immigration was almost exclusively in the hands of the CNMI, while today federal control over CNMI immigration includes provisions for foreign workers, tourists, and investors. In addition, economic decisions over minimum wage were made by Washington in 2007 and 2011 and not by the Government of Saipan (United States Government Accountability Office, 2011, pp. 45-46, 58-59). These decisions on the federal level show on the one hand the diminished sovereignty of the CNMI over immigration and federal minimum wage, but, on the other hand, these proceedings reflect the integration of the CNMI through its constitutional link with the United States resulting in a form of hybrid sovereignty. The only other covenant of this kind exists between Washington, DC and Puerto Rico.

Presently, the Northern Marianas are experiencing growing tensions between the US and China. Asian tourists and gamblers have discovered the region as a travel destination, and the influx of Chinese money in the form of tourists and development projects has become a major factor for the island economy. At the same time, the US military intends to use Tinian and Pagan as live-fire training sites and is building up its Marine units on the islands (Blades, 2016). These developments reflect the geopolitical competition between China and the US: China's Maritime Strategy, elaborated by Admiral Liu Huaqing, argues for the exertion of sea control out to the First Island Chain (Kyushu, Ryukyu Islands, Taiwan, The Philippines, and Borneo) by 2000 and consecutively to the Second Island Chain (Honshu, Northern Marianas, Palau, and West Papua). This strategy leads to tensions with the US, which established numerous bases in the region after the Second World War to contain the former Soviet Union and protect its allies in Japan and South Korea. The precise objectives of the Chinese Maritime Strategy remain disputed by national security scholars, yet the continuing expansion and modernization of the People's Liberation Army Navy in the South China Sea are unambiguous (Holmes \& Yoshihara, 2010, pp. 14-44). In these burgeoning geopolitical tensions, the CNMI constitutes an important part of the informal US empire in the Pacific.

The last decade has seen a rise in intra-pacific diplomacy, and the CNMI was awarded observer status at the Pacific Islands Forum in 2011 (Maclellan, 2015, p. 264). As a consequence, the CNMI today participates in this regional forum as an observer, while the US takes part as a dialogue partner. Although the Northern Marianas' engagement in the Pacific Islands Forum is characterized by a "sense of detachment" based on different colonial histories in the Pacific (Gallen, 2015, pp. 177-180), the status is more relevant than Saipan's current political activity. Participation in the Pacific Islands Forum opens up diplomatic avenues that clash with a conventional understanding of colonialism and decolonization. In this forum, the CNMI can demonstrate its own pursuit of political objectives without close consultations with the former administering power. In the $21^{\text {st }}$ century, the CNMI can 
therefore be described to exist in hybrid sovereignty with the US, is part of Washington's informal empire, and is to a degree active in regional diplomacy.

\section{Federated States of Micronesia, Republic of the Marshall Islands, and Republic of Palau}

The Marshall Islands, the Federated States of Micronesia (FSM), and Palau chose a different path from the Northern Mariana Islanders. Driven by aspirations for national sovereignty and full self-government, and in adherence with UN regulations, the remaining three districts of the TTPI achieved independence in free association with the United States (Stayman, 2009, pp. 8-9). All three sovereign states continue to receive US assistance and are part of the US mutual defense system. For analytical purposes, it makes sense to consider all three compact states together because of the similarity of their affiliation. Contemporary commentators appropriately judged the compacts as "instruments of US imperialism" (Boneparth \& Wilkinson, 1995, p. 67) because Washington primarily secured military-strategic interests with all three newly independent island states, not accepting a full transfer of power in the field of defense.

In the course of the dissolution of the Pacific Trust Territory, curious and complex international events occurred. The Soviet Union blocked the termination of the trusteeship in the Security Council on legal and political grounds, although local referenda had been held in accordance with UN law. Potentially, Moscow feared the application of such a proceeding on Soviet territory. With the Security Council blocked, the US, UK, and France put the vote before the Trusteeship Council, which could decide by majority voting without a veto. On 28 May 1986, the trusteeship for the FSM and Marshall Islands was terminated, and Palau remained the last part of the Pacific Trust Territory. With the fall of the Soviet Union, the veto threat receded and a Security Council action became possible. At this point, a curious letter from the governor of the CNMI circulated in the UN calling for further UN "protection" against the United States. This letter ran counter to the objective of the South Pacific Forum, which welcomed the termination and supported it outright. In the end, only Cuba voted 'no' in the Security Council on 22 December 1990, ironically citing anticolonialism to prevent the decolonization of the Trust Territory (Boneparth \& Wilkinson, 1995, pp. 62-65).

Palau's independence came later, after the US as administering power insisted on seven plebiscites which in the end overrode the nuclear-free clauses of its constitution. President Salii described the final result as a matter of economic survival due to American pressure and the dependency of his island polity on US funding (New York Times, 1987; Roff, 1991, p. 187). After Palau had gained its independence, the relationship between the three compact states and the US changed substantially. All three compact governments have become full UN members and have overcome the argument that microstates lack the resources for self-sufficiency or ability to contribute to UN efforts. This argument was legally discredited by the Principality of Lichtenstein's admission to the UN in 1990 (Boneparth \& Wilkinson, p. 66) and argumentatively questionable, because it would negate the possibility of self-determination and independence on economic grounds. Although from a realistic perspective on international relations, hard factors (territory, power, economy, and population) matter, selfdetermination and identity throughout history have not always been contingent upon these factors. All three island polities have become UN members, the FSM and Marshall Islands in 1991 and Palau in 1994. In a conventional sense, all have passed from an era of colonialism through a phase of decolonization and are now sovereign and independent island states.

However, the free association agreements contain "mutual security pacts which specifically prevented full and final decolonization in the future" (Payne, 1993, p. 121). In addition, the economic dependency between the island states and the US constitutes a tension between the economic benefits for Pacific islanders and their aspirations for further steps 
towards decolonization. In the FSM, Marshall Islands, and Palau but also in the US-affiliated territories, the high standard of living for many islanders is connected to outside funding and job opportunities in continental America as well as jobs funded by the United States government. This has led to a paradox of decolonization which further questions the usefulness of the term for contemporary observations: economically, "territories do better than the freely associated states, which in turn do better than independent states" (Firth, 2000, p. 327). As a result, most Pacific islanders seem content with their economic dependency, knowing the constraints island states face. American benefits have become accepted despite wrongdoings in the colonial past and nuclear testing in the Marshall Islands (Henningham, 1995, p. 50), and these social, cultural, and economic ties should be considered as remnants of colonial domination (Borofsky, 2000, p. 304)

In order to delineate decolonization in the FSM, Marshall Islands, and Palau, the past and present critique has to be addressed that all three entities should not be considered independent. After the termination of the trusteeship, all three island polities were granted full selfgovernment and achieved UN membership. Free association with the US and independence now coexist (Petersen, 1995, p. 80). It is a worthwhile observation that "formal independence does not guarantee de facto independence" (Quanchi \& Adams, 1993, p. 150), but this is not a problem unique to island states in the Pacific or elsewhere. Small states in international relations generally pursue strategies of integration, bandwagoning, or alliance with relatively stronger states: this holds true for the Baltic States after the fall of the Soviet Union as well as for every other state in pursuit of interests that surpass its capacities. For the FSM, Marshall Islands, and Palau, it is important to note that they became members of the UN as well as the South Pacific Forum "on the basis that they were fully internally self-governing and able to implement Forum decisions within the region" (Henningham, 1995, p. 48).

The current discussion about the possible end or renewal of the compact between the FSM and the US demonstrates the power asymmetry between both actors and the growing Chinese-US competition over influence in Micronesia (Matelski, 2006). The move taken and the language used at the Nineteenth Congress of the Federated States of Micronesia (2015) to end the compact five years earlier in 2018 rather than in 2023 was a reflection on current disputes over federal funding, economic aid, and immigration and tourist visas. The resolution mentions indignation over not being treated as a sovereign equal by Washington, but the text focuses on financial and economic matters. The language cannot be compared to past documents by African and Asian leaders from the 1960s which spoke of 'national liberation' or an 'end to colonialism'. The three island states have become independent actors in regional affairs, and except for control over defense matters, the FSM, Marshall Islands, and Palau exert partial sovereignty over their affairs. Decolonization has become an outworn term in these cases, and mechanisms of international relations can offer more precise results on the questions of political and economic dependence and independence.

\section{American Samoa}

American Samoa, together with Guam, is one of the five remaining unincorporated territories of the United States, the others being the Northern Mariana Islands, US Virgin Islands, and Puerto Rico. These unincorporated territories exist in an unresolved political status and theoretically could gain US statehood, become freely associated with, or become independent from, Washington (Stayman, 2009, p. 9). In addition, American Samoa and Guam are the only two island polities in US affiliation which are still on the UN list of Non-Self-Governing Territories and are under the observation of the UN Special Committee on Decolonization (or Committee of 24), established in 1961 to monitor the implementation of the Declaration on the Granting of Independence to Colonial Countries and Peoples. Carlyle Corbin, UN expert on self-determination of island polities, argues that such "political dependency 
arrangements are clearly within the purview of the international decolonization process" (United Nations, 2010b, p. 1).

In 2002, the government of American Samoa in Pago Pago wanted to be struck off that list, because independence was not a political goal (Rothermund, 2006, p. 44). In 2015, however, the desire was expressed to remain on the list. In a document from 13 June 2013 entitled 'Decolonization issue regarding American Samoa', the current position of the government in Pago Pago becomes clearer: the American Samoan governor underlined that American Samoa was not a colony but a United States territory. Although "being part of the United States family was really a matter of self-determination" (United Nations, 2016, p. 6), the governor expressed the real reason for staying on the decolonization list at the same time: "Until the people of American Samoa had exercised their right to determine for themselves their future political status, it was perhaps best that American Samoa remained on the United Nations decolonization list" (United Nations, 2016, p. 7). No rash actions were demanded because American Samoans benefit economically from their status as US nationals, which allows them to work or reside anywhere in the United States-but are not allowed to vote in the US elections. The comparison to West Samoa (today, the Independent State of Samoa), which became independent in 1962, is telling: American Samoa's neighbors in Savai'i and Upolu have a lower per capita income and lower educational standard (Crocombe, 1995, p. 273).

The terminology of 'decolonization' seems to be questionable for the case of American Samoa: American Samoa is a part of the United States-although unincorporated-but substantially self-governing and, so far, part of the United States by self-determination. There seems to be neither consent nor a firm intent by its population to become fully independent, which casts doubt on key elements of colonialism and the initiation of conventional decolonization. Pago Pago does not fight against domination by cultural foreigners or to gain full constitutional sovereignty. Although American culture influences individual lifestyles, American Samoans retain their laws and cultural norms and govern themselves. What Pago Pago is missing is adequate political representation to shape jurisdiction with regard to its economic situation. Pago Pago sends only one delegate to the US Congress who has no voting rights, and final authority over American Samoa rests with the US President and the Department of the Interior. As a result, American Samoans can vote on their constitution, but it needs to be approved by the US government (United Nations, 2015, p. 7).

Clearly, American Samoa is not fully independent, and its sovereignty is in question. Yet it is self-governing and pursues its political objectives-first and foremost, the clarification of American Samoa's political status. At the UN decolonization seminar in Nicaragua, American Samoa's governor Lolo Matalasi Moliga acknowledged the beneficial relationship with the US but stated that "its current political status as an unincorporated and unorganized US territory is neither sustainable nor economically secure" (RNZ, 2015). Moliga mentioned full independence, free association, a commonwealth, or an organic act as possible solutions for American Samoa's future. In pursuit of these objectives, Moliga has established the Office of Political Status, Constitutional Review and Federal Relations. The new department is integrated into the governor's office and looks "at issues such as self-determination and the pros and cons of further integration with the United States, including citizenship and representation in Congress" (RNZ, 2016).

American Samoa's affirmation to remain on the UN list of Non-Self-Governing Territories was triggered by "vagaries" in Washington, as mentioned in the governor's official statement, after accepting the invitation to the UN seminar on decolonization in Nicaragua. The statement is less an attack on the close relationship between American Samoa and the US but rather a strong demand for more control over policy areas that are important to Samoans. One example is the opposition of the American Samoan government to the legal fight of some of its citizens (Tuaua v. United States) to gain full US citizenship "on the ground that it would threaten their cultural practices" (Ponsajune, 2016). Another example is free 
trade agreements into which the United States entered and that in turn affected American Samoa (UN, 2016, p. 7): "Whether the territory is delisted or not [...] we are exposed to actions of Congress affecting us in ways not contemplated because of our tiny land area, located in a large ocean, thousands of miles from the continental US, and economic circumstance" (Pireport, 2016).

The dependency on two tuna canneries for job generation has made American Samoa vulnerable and keeps the islands in financial and economic dependency on US funding, especially since one of the canneries has now closed (Associated Press, 2016). This development shows the fundamental constraints island polities are facing and underlines the difficulty of the term decolonization in an interconnected global economy in connection with historical processes. In terms of American Samoa's political aspirations, one could use 'decolonization' in a classical way to describe the absence of a complete transfer of power from the administering power to the indigenous government. Yet American Samoa's political status complicates its application: on the one hand, American Samoa could claim unfinished decolonization because a foreign power still influences its constitutional and economic affairs; on the other, American Samoans have become active agents in negotiating their own political status as part of the US political system.

Pago Pago will probably pursue a path for greater sovereignty in certain policy fields, for example in economic matters, but remain a part of the United States. One can expect a process of "internal constitutional evolution" (United Nations, 2010b, p. 2) which could result in an even closer integration with the US through an organic act or commonwealth status. An indication of Pago Pago's burgeoning desire for a more autonomous political status is displayed by its observer status in the Pacific Islands Forum and its intention to become a full member. Having received an invitation for full membership, which has recently been achieved by the French territories of French Polynesia and New Caledonia, Governor Lolo Moliga stated that "American Samoa wants to strengthen ties with its Pacific neighbors but also its association with the United States" (Pireport, 2016b).

American Samoa's experiences illustrate how the issues of decolonization can gradually flow into regular political negotiations when questions of liberation or nationalism stop playing a decisive role. The economic challenges of island states and constraints on selfsufficiency in a modern world challenge the outworn term even more. While the process of decolonization recedes, Pago Pago's relationship with Washington can better be characterized to be in a state of hybrid sovereignty.

\section{Guam}

Guam, the largest island of the Marianas, remains firmly in a state of "imperial limbo" (Fojas, 2015, p. 168) and is defined by tourism and militarism. As part of the strategic island trio with Hawai'i and the Philippines, Guam constitutes an essential asset for the US military in the Pacific. The US Navy exercised undisputable powers until 1950, when a civilian government with separation of powers and a bill of rights was established by the Organic Act of Guam, and the local population gained US citizenship. After 277 years under the rule of three different imperial powers, this move by the United States seemed in accordance with the general idea of decolonization. Guamanians' citizenship, though, can still be revoked by Congress, and since 2009 a military buildup has led to a retransfer of economic and political power to the US military (Fojas, 2015, pp. 167-170). Guam is dominated by the US military, and its self-government is only marginally developed, underlining the case that Guam's decolonization remains imperfect.

In Guam, the contest between the indigenous population and American interests is a question of land and self-determination of the local Chamorro people; in Firth's useful differentiation, decolonization in Guam is to be considered redistributive and culturally 
assertive (Firth, 2000, p. 315). The notion of political or constitutional independence remains considerably unlikely because of Guam's strategic value in the past and because of the present growing geopolitical competition between China and the US (O'Keefe, 2015, p. 127). In 1994, Joseph F. Ada, former Governor of Guam, introduced himself to the Clinton Administration as "Governor of the American colony of Guam" and expressed Guam's desire to end its colonial status (Firth, 2000, p. 330). In 1997, the Legislature of Guam set up a Commission on Decolonization "to educate the people of Guam of the various political status options available, should Guam be allowed to pursue a change in its political status and relationship with the United States" (Tolentino, 2014). According to Principle VI, laid down by UN Resolution 1541 (XV), whether or not a Non-Self-Governing Territory has reached self-government, Guam should be able to choose freely between independence, free association, or integration (United Nations, 1960). Washington's past behaviour towards the successor states of the Pacific Trust Territory indicates that comprehensive independence is neither a real option nor a goal pursued by Guamanians who overall want to remain US citizens.

On account of Guam's strategic value, Washington has been mainly hesitant and obstructive in letting the indigenous population determine their political status. In a political dimension, the Chamorros are not fully decolonized. Cultural, social, and economic dimensions are more blurred because of the small size of the island and its enmeshed history with the United States: for some residents, a continuing connection between colonialism and militarization exists, while others cherish the benefits of the historically grown relationship (Letman, 2016). Against this backdrop, the intention remains to stay to some degree affiliated with Washington. Guam demanded more autonomy during the Clinton and Bush administrations and introduced a bill for commonwealth status (Crocombe, 1995, p. 272), which could lead to complete internal self-government, return of federally held property, and influence on the application of federal legislation on Guam, similar to that of Puerto Rico or the CNMI (Henningham, 1995, p. 61).

The bill's failure has been attributed to the definition of 'self in self-government. While officials in Guam insist on the "residual sovereignty of the Chamorro people," the administrations in Washington have rejected the bill on the grounds that it would exclude the settler population from voting on Guam's future political status (Quimby, 2014). With Chamorros in the minority, the inclusions of all Guamanians-all legal residents of the island-in a future plebiscite would discard the concept of the Chamorros' exercise of residual sovereignty in their self-determination. This highlights some of the problems identified by Androus and Greymorning (2016) with respect to differential assessments of sovereignty on the parts of settler populations and indigenous islanders.

The leeway Washington gives to Guam is imperfect and incomplete, demonstrating a classic centre-periphery relationship from the colonial era, because Washington deliberately postpones local self-determination and obstructs a possible Commonwealth with Guam. Yet, there are signs that Washington shows some intent to adhere to the principles laid down in Article 73 of the UN charter. At the Pacific Regional Seminar on Decolonization in Managua in 2016, it was noted that for the first time in recent memory Washington met its obligation to grant $\$ 300,000$ to the government of Guam for political status education (United Nations, 2016b). Guam also exercises a small measure of self-government by sending a non-voting delegate to the US Congress-which constitutes a first but not final step towards political self-determination. More importantly, Washington has not infringed upon Guam's path to participate in regional diplomacy. Like American Samoa and the CNMI, Guam attained observer status in the Pacific Islands Forum in 2011 (Maclellan, 2015, p. 264).

The relationship is further complicated by the impact of settler colonialism over the course of Guam's history, and the influence of the US military constrains substantially the ability of local communities to influence political processes (Natividad \& Kirk, 2010, p. 2). Whether or not the support of education on Guam's future political status in 2016 was a 
goodbye present from President Obama or the beginning of a real renegotiation between Washington and the government in Hagåtña remains to be seen. Presently, Guam remains in a strongly diminished status of hybrid sovereignty, with heavy constraints on self-government. The power disparity and few policy fields in which Chamorros can exercise sovereignty characterizes this remaining colonial relationship.

\section{Conclusions}

"The simple constitutional model of Pacific Islands decolonization [...] no longer encompasses the complex reality of the issue" (Firth, 2000, p. 315). Firth's assessment and research on the state of decolonization at the turn of the 21 st century and the diverse application of the term remains a solid theoretical basis for current observations about the Pacific. The variety of approaches to decolonization in Oceania exacerbates the difficulty of the term. Decolonization in its ideological form has lost its momentum in the US-affiliated island polities of the Pacific because ideas about national liberation and the fight against colonialism do not coincide with the political strategies of Pacific islanders at this stage of history. Sovereignty in the form of independent statehood is not at the top of the demands in American Samoa or Guam, and today "many Islanders in territories no longer want to be decolonized" (Firth, 2000, p. 331). The FSM, Marshall Islands, Palau, and the CNMI have all gained independence and remain in varying degrees connected to Washington through forms of hybrid and partial sovereignty. For these island states, decolonization in its full, constitutional meaning would result in a loss of federal funding, a drop in their standards of living, and would tear apart the interconnected history and economic ties of the past. The absence of full constitutional sovereignty, though, should not be considered as an obstacle to analyze the state of decolonization in the Pacific. Historians of island-centred histories are well advised to heed Aldrich's assessment that independence or the lack thereof is not "the logical end-point of decolonization" (Aldrich, 2000, p. 174).

Based on Firth and Aldrich's observations, Oceania has arrived in a "postdecolonial era" (Firth, 2000, p. 332). According to Osterhammel's categorization, Washington protects its interests either through some form of informal empire (second grade) or a non-colonial but dominant approach (third grade) - the first grade being outright formal empire. The Federated States of Micronesia, the Marshall Islands, and Palau would nearly fit into the third category, but the special treaties reserved for the US in security issues keep these islands partially integrated in America's informal empire (Osterhammel, 1995, pp. 25-26).

Especially Guam's history and further political status are marked by an American imperial approach. At the same time, the path of internal political evolution in American Samoa and Guam in constitutional links with the US blurs the lines between informal empire and emerging autonomous forms of government: in both cases, developments could result in a commonwealth with the US, free association, or theoretically statehood like Hawai'i. Their common path seems to be further integration with the US in economic and political dimensions, while asserting cultural independence and far-reaching self-government, resulting in and expanding their state of hybrid sovereignty.

In the Pacific, as in Africa and Asia, "huge inequalities remained as the dynamic of world politics. But colonial rule disappeared" (Darwin, 2000, p. 7). American Samoa and the CNMI, as well as the states in free association, are good examples of this transition-without excluding the bitterness over nuclear testing on the Marshall Islands or the strong influence on the formulation of Palau's constitution. The pursuit of autonomy without full sovereignty by these island polities corresponds with the observation that "the relationship between colonial and postcolonial is not a dialectical one" (Baldacchino, 2010, p. 196). Guam constitutes the remaining hard case, where the term decolonization could still be applied, due to the incomplete process of self-determination of the Chamarro people. 
The US-affiliated island states underline the unsuitability of the term decolonization for the contemporary Pacific. Gungwu's observation of the history of Southeast Asia is transferrable to Oceania: the "American role in the international relations of the region is much greater than anything that the word 'decolonization' can conjure up" (Gungwu, 2003, p. 273). Due to Washington's economic and military strength, as well as interest in the region, it exerts a strong influence on its smaller partners, all of which have chosen some form of affiliation with Washington. The contemporary situation can thereby best be described as a typically asymmetric relationship pattern in a postcolonial diplomatic system (Osterhammel, 1995, p. 26; Fry \& Tarte, 2015, p. 4).

An international approach, based on constitutional and political dimensions, has been criticized for its focus on decisions made in the metropolitan power, because it neglects the perspective of the indigenous population (Mar, 2016, p. 9). In order to revise and question the application of the concept of decolonization in the cases of US-affiliated islands, the statement of the Dutch historian Henk Wesseling rings true: "Decolonisation has finished. It definitely belongs to the past. Yet somehow it has refused to become history" (ctd. in Thorn, 2000 , p. 4). The US-affiliated islands-especially Guam-show the persisting residue of the process of decolonization in the framework of Washington's informal empire in the Pacific. While the centre-periphery relationship and the political and economic asymmetric dependence on the US remains, statehood, free association, and territorial status "represent historical and constitutional alternatives to independence rather than failures of decolonization" (Aldrich, 2000, p. 174). The "hybrid jurisdictions" (Levine \& Roberts, 2005, p. 279) are a path for contemporary island polities in US-affiliation to achieve a high degree of self-determination, notwithstanding their limited resources and relatively weak international positions. For American Samoa, Guam, the Commonwealth of the Northern Mariana Islands, the Marshall Islands, the Federated States of Micronesia, and Palau, decolonization has above all become a historical term and unfitting for the new relationships that have emerged in the Pacific since the 1970s and the demise of the Trust Territory of the Pacific islands in 1994.

\section{Acknowledgments}

The author expresses his sincere gratitude to the scholarly patience and benevolence of the Island Studies community which fostered the elaboration of this theoretical approach.

\section{References}

Aldrich, R. (2000). The decolonisation of the Pacific Islands. Itinerario, 3-4(24), 173-191. https://doi.org/10.1017/S0165115300014558

Androus, Z., \& Greymorning, N. (2016). Critiquing the SNIJ hypothesis with Corsica and Hawai'i. Island Studies Journal, 11(2), 447-464.

Ashcroft, B., \& Griffiths, G., \& Tiffin, H. (2007). Post-colonial studies: the key concepts. Abingdon: Routledge.

Associated Press. (2016). Tuna cannery in American Samoa to halt production. 13 October. http://www.staradvertiser.com/2016/10/13/business/business-breaking/tunacannery-in-american-samoa-to-halt-production/

Baldacchino, G., \& Hepburn, E. (2012). A different appetite for sovereignty? Independence movements in subnational island jurisdictions. Commonwealth \& Comparative Politics, 50(4), 555-568. https://doi.org/10.1080/14662043.2012.729735

Baldacchino, G. (2010). 'Upside down decolonization' in subnational island jurisdictions: questioning the 'post' in postcolonialism. Space and Culture, 13(2), 188-202. https://doi.org/10.1177/1206331209360865 
Baldacchino, G., \& Milne, D. (2006). Exploring sub-national island jurisdictions: an editorial introduction. The Round Table, 95(386), 487-502. https://doi.org/10.1080/00358530600929735

Blades, J. (2016). US military plans present difficult balancing act for Marianas. RNZ, 22 August. http://www.radionz.co.nz/international/pacific-news/311582/us-militaryplans-present-difficult-balancing-act-for-marianas

Boneparth, E., \& Wilkinson, J.M. (1995). Terminating trusteeship for the Federated States of Micronesia and the Republic of the Marshall Islands: independence and self-sufficiency in the post-Cold War Pacific. Pacific Studies, 2(18), 61-77.

Borofsky, R. (ed.). (2000). Rememberance of Pacific pasts. Honolulu: Hawai'i University Press. Crocrombe, R. (1995). The Pacific Islands and the USA. Honolulu: East-West Center.

Darwin, J. (2000). Diplomacy and decolonization. The Journal of Imperial and Commonwealth History, 3(28), 5-24. https://doi.org/10.1080/03086530008583096

Firth, S. (2000). Decolonization. In R. Borofsky (ed.). (2000). Remembrance of Pacific pasts (pp. 314-332). Honolulu: Hawai'i University Press.

Firth, S. (1989). Sovereignty and independence in the contemporary Pacific. The Contemporary Pacific, 1-2(4), 75-96.

Fojas, C. (2015). Islands of empire: pop culture and US power. Austin: University of Texas Press.

Frey, M. (2002). Drei Wege zur Unabhängigkeit. Die Dekolonisierung in Indochina, Indonesien und Malaysia nach 1945. Vierteljahreshefte für Zeitgeschichte, 3(50), 399-433.

Fry, G., \& Tarte, S. (2015). Pacific diplomacy and decolonisation in the $21^{\text {st }}$ century. In G. Fry \& S. Tarte (eds.) The new Pacific diplomacy (pp. 3-19). Acton, Australia: ANU Press. https://doi.org/10.22459/NPD.12.2015

Gallen, S.L. (2015). In G. Fry \& S. Tarte (eds.) The new Pacific diplomacy (pp. 175-188). Acton, Australia: ANU Press.

Grydehøj, A. (2016). Navigating the binaries of island independence and dependence in Greenland: decolonisation, political culture, and strategic services. Political Geography, 55, 102-112. https://doi.org/10.1016/j.polgeo.2016.09.001

Gungwu, W. (2003). The limits of decolonization. In M. Frey, R.W. Pruessen, \& T.T. Yong (eds.) The transformation of Southeast Asia: international perspectives on decolonization (pp. 268-275). Armonk, NY: M.E. Sharpe.

Hanlon, D.L. (1998). Remaking Micronesia: discourses over development in a Pacific territory, 19441982. Honolulu: University of Hawaii Press.

Henningham, S. (1995). The Pacific Island states. London: Macmillan Press. https://doi.org/10.1057/9780230372436

James, A. (1986). Sovereign statehood: the basis of international society. London: Allen \& Unwin.

Jansen, J.C., \& Osterhammel, J. (2013). Dekolonisation: Das Ende der Imperien. München: Beck. https://doi.org/10.17104/9783406654657

Letman, J. (2016). Guam: where the US military is revered and reviled. The Diplomat, 29 August. http://thediplomat.com/2016/08/guam-where-the-us-military-is-reveredand-reviled/

Levine, S., \& Roberts, N. (2005). The constitutional structures and electoral systems of Pacific Island states. Commonwealth \& Comparative Politics, 43(3), 276-295. https://doi.org/10.1080/14662040500304866

Mahan, A.T. (1935). The influence of sea power upon history, 1660-1783. Boston: Little, Brown \& Co.

Maclellan, N. (2015). Pacific diplomacy and decolonisation in the 21st century. In G. Fry \& S. Tarte (eds.) The new Pacific diplomacy (pp. 263-381). Acton, Australia: ANU Press. https://doi.org/10.22459/NPD.12.2015.21

Matsuda, M. (2006). Ocean-based histories: the Pacific. The American Historical Review, 3(111), 758-780. https://doi.org/10.1086/ahr.111.3.758 
Mar, T.B. (2016). Decolonisation and the Pacific: indigenous globalisation and the ends of empire. Cambridge: Cambridge University Press.

Matelski, T.R. (2016). America's Micronesia problem. The Diplomat, 19 February. http://thediplomat.com/2016/02/americas-micronesia-problem/

Natividad, L.L., \& Kirk, G. (2010). Fortress Guam: resistance to US military mega-buildup. The Asia-Pacific Journal, 8(19), 1-17.

New York Times (1987). Palau drops nuclear-free status. New York Times, 7 August. http://www.nytimes.com/1987/08/07/world/palau-drops-nuclear-free-status.html

Nineteenth Congress of the Federated States of Micronesia, Third Special Session. (2015).

C.R. NO.19-155.

http://www.fsmcongress.fm/pdf\%20documents/19th\%20Congress/RESOLUTIONS /CR\%2019-155.pdf

O'Keefe, M. (2015). The strategic context of the new Pacific diplomacy. In G. Fry \& S. Tarte (eds.) The new Pacific diplomacy (pp. 125-136). Acton, Australia: ANU Press. https://doi.org/10.22459/NPD.12.2015.11

Osterhammel, J. (2002). Kolonialismus. Geschichte - Formen - Folgen. München: Beck.

Payne, A. (1993). The politics of small state security in the Pacific. The Journal of Commonwealth \& Comparative Politics, 31(2), 103-133. https://doi.org/10.1080/14662049308447658

Petersen, G. (1998). Strategic location and sovereignty: modern Micronesia in the historical context of American expansionism. Space and Polity, 2(2), 179-205. https://doi.org/10.1080/13562579808721779

Petersen, G. (1995). Why is Micronesian 'independence' an issue? In B. Lal \& H. Nelson (eds.) Lines across the sea (pp. 69-83). Brisbane: Pacific History Association.

Pireport. (2016). American Samoa to participate in UN decolonization seminar. 31 May. http://www.pireport.org/articles/2016/05/31/american-samoa-participate-undecolonization-seminar

Pireport. (2016b). American Samoa looks at becoming full member of Pacific Islands Forum. 22 September. http://www.pireport.org/articles/2016/09/22/american-samoalooks-becoming-full-member-pacific-islands-forum

Ponsajune, C.D. (2016). Are American Samoans American? New York Times, 8 June. http://www.nytimes.com/2016/06/08/opinion/are-american-samoansamerican.html? $\mathrm{r}=0$

Quanchi, M., \& Adams, R. (eds.) (1993). Culture contact in the Pacific. Cambridge: Cambridge University Press.

Quimby, F. (2014). Guam Commonwealth Act. $\quad$ http://www.guampedia.com/guamcommonwealth-act/

RNZ. (2016). American Samoa agency to review constitutional matters. 21 April. http://www.radionz.co.nz/international/pacific-news/302062/american-samoaagency-to-review-constitutional-matters

RNZ (2015). American Samoa addresses UN decolonisation meeting. 21 May. http://www.radionz.co.nz/international/pacific-news/274227/american-samoaaddresses-un-decolonisation-meeting

Roff, S.R.. (1991). Overreaching in paradise: United States policy in Palau since 1945. Juneau: Denali Press.

Rothermund, D. (2006). The Routledge companion to decolonization. London \& New York: Routledge.

Shipway, M. (2008). Decolonisation and its impact: a comparative approach to the end of the colonial empires. Malden: Blackwell.

Stayman, A. (2009). US territorial policy: trends and current challenges. Honolulu: East-West Center. 
Thorn, G. (2000). End of empires: European decolonisation 1919-80. London: Hodder \& Stoughton.

Tolentino, D. (2014). Commission on decolonization. http://www.guampedia.com/commission-on-decolonization/

United Nations. (2016b). Speakers urge administering powers to address impact of nuclear testing, military build-up in Pacific territories, as regional decolonization seminar continues. GA/COL/3291. 1 June. http://www.un.org/press/en/2016/gacol3291.doc.htm

United Nations (2016). Special committee on the situation with regard to the implementation of the declaration on the granting of independence to colonial countries and peoples: American Samoa. A/AC.109/2016/1. 3 March. http://www.un.org/ga/search/view_doc.asp?symbol=A/AC.109/2016/1

United Nations (2015). Resolutions adopted by the General Assembly on 9 December 2015. A/RES/70/102 http://www.un.org/ga/search/view doc.asp?symbol=A/RES/70/102

United Nations (2010b). Pacific regional seminar on the implementation of the Second International Decade for the Eradication of Colonialism. assessment of decolonization process in today's world. PRS/2010/DP.6. http://www.un.org/en/decolonization/pdf/dp_2010_corbin_7.pdf

United Nations (2010). Third international decade for the eradication of colonialism, resolution 65/119 adopted by the General Assembly on 10 December 2010. http://www.un.org/en/ga/search/view doc.asp?symbol=A/RES/65/119

United Nations. (1960). Principles which should guide members in determining whether or not an obligation exists to transmit the information called for under Article $73 \mathrm{e}$ of the Charter. https://documents-ddsny.un.org/doc/RESOLUTION/GEN/NR0/153/15/IMG/NR015315.pdf?OpenElement

United States Government Accountability Office - GAO (2011). American Samoa and the Commonwealth of Northern Mariana Islands. Employment, earnings, and status of key industries since minimum wage increases began. Washington, D.C/ GAO-11-427.

White House, Office of the Press Secretary. (2011). Remarks by President Obama and Prime Minister Gillard of Australia in Joint Press Conference, Parliament House. Canberra: 16 November. 